\title{
PERUBAHAN SIFAT FISIKOKIMIA TEPUNG SORGUM SETELAH HIDROLISIS PARSIAL DENGAN ENZIM $\alpha$-AMILASE DARI Bacillus Sp. (TERMAMYL ${ }^{\circledR}$ )
}

\author{
Muhammad Fadhlillah ${ }^{1}$, Safri Ishmayana ${ }^{2}$, Idar Idar $^{3}$, Soetijoso Soemitro ${ }^{2}$, Toto Subroto ${ }^{2, *}$ \\ ${ }^{1}$ Program Studi Teknologi Pangan, Fakultas Teknik, Universitas Pasundan, Jln. Dr. Setiabudi No. 193, Bandung, \\ 40153 \\ ${ }^{2}$ Departemen Kimia, Fakultas Matematika dan Ilmu Pengetahuan Alam, Universitas Padjadjaran, Jln. Raya \\ Bandung Sumedang km. 21, Jatinangor, Sumedang, Jawa Barat 45363 \\ ${ }^{3}$ Sekolah Tinggi Farmasi Bandung, Jl. Soekarno Hatta No. 754 Bandung \\ *Alamat Korespondensi: t.subroto@unpad.ac.id
}

\begin{abstract}
Abstrak: Salah satu upaya untuk memperbaiki sifat tepung adalah dengan menggunakan perlakuan enzimatik dengan enzim $\alpha$-amilase. Sifat fisikokima tepung sorgum yang sudah dihidrolisis sebagian dapat mengalami perubahan. Penelitian kelompok kami sebelumnya menunjukkan bahwa $\alpha$-amilase komersial (Termamyl $^{\circledR}$ ) memiliki kemampuan untuk mendegradasi tepung sorgum. Pada penelitian ini sifat tepung sorgum yang telah didegradasi ditentukan yaitu mencakup volume pengembangan, viskositas, dan kristalinitas. Hasil penelitian ini menunjukkan bahwa terjadi penurunan volume pengembangan sebesar $60 \%$ pada suhu $95^{\circ} \mathrm{C}$, penurunan suhu pembentukan pasta dari $80-85^{\circ} \mathrm{C}$ menjadi $70-75^{\circ} \mathrm{C}$, dan pengurangan refleksi kristalit yang menunjukan perubahan kristalinitas dari semikristalin menjadi amorf pada tepung sorgum terhidrolisis bila dibandingkan dengan tepung sorgum sebelum hidrolisis.
\end{abstract}

Kata kunci: sorgum, $\alpha$-amilase, tepung, sifat fisikokimia

Abstract: One of the efforts to improve properties of flour is by enzymatic treatment using $\alpha$-amylase. Physicochemical properties of sorghum flour can be changed after being partially hydrolyzed. Our previous work indicated that commercially available $\alpha$-amylase (Termamyl ${ }^{\circledR}$ ) has ability to degrade sorghum flour. In the present work, we determine the properties of the partially hydrolyzed sorghum flour which include swelling volume, viscosity and crystallinity. The results of the present work indicated that there is a $60 \%$ decrease in swelling volume at $95^{\circ} \mathrm{C}$, temperature decrease in pasta forming from $80-85^{\circ} \mathrm{C}$ to $70-75^{\circ} \mathrm{C}$ and decrease in crystalyte reflection which indicate the cristalinity shifted from semicrystaline to amorphous state in hydrolized sorghum flou compae to native sorghum flour.

Keywords: sorghum, $\alpha$-amylase, flour, physicochemical properties

\section{PENDAHULUAN}

Tepung terigu merupakan bahan dasar utama yang digunakan untuk pembuatan roti (Phattanakulkaewmorie et al. 2011). Namun, terigu mengandung protein gliadin yang merupakan salah satu protein pembentuk gluten. Gliadin dapat menyebabakan penyakit seliak, yaitu suatu penyakit autoimun yang ditandai dengan rusaknya lapisan mukosa usus halus (Fasano \& Catassi, 2001).

Sorgum telah dikembangkan sebagai bahan dasar alternatif yang digunakan sebagai bahan pembuatan roti (Phattanakulkaewmorie et al. 2011; Schober et al 2005). Roti yang dibuat dengan bahan dasar sorgum bebas dari gluten, sehingga aman untuk dikonsumsi oleh orang-orang yang memiliki penyakit seliak (Schober et al 2005).

Meskipun gliadin dapat menyebabkan terjadinya penyakit seliak, peranannya sebagai salah satu komponen pembentuk gluten menjadikannya sangat penting untuk membentuk tekstur roti yang disukai oleh konsumen (Lagrain et al. 2013). Tidak adanya gluten pada sorgum menyebabkan adonan yang encer dan sifat roti setelah dipanggang yang kurang baik, seperti warna yang kurang menarik dan tekstur yang keras (Phattanakulkaewmorie et al. 2011).
Untuk memperbaiki sifat roti yang dibuat dengan menggunakan sorgum, dapat dilakukan modifikasi seperti melalui proses oksidasi, hidrolisis dengan asam, substitusi gugus hidroksil pada unit $\alpha$-Dglukopiranosil, irradiasi $\lambda$, perlakuan hidrotermal, perlakuan dengan tekanan tinggi, penggilingan, dan modifikasi enzimatik (Zhu 2014).

Modifikasi dengan bantuan enzim $\alpha$-amilase diketahui dapat memeperbaiki kualitas produk roti sorgum yang dihasilkan (Onyango et al. 2010a). Selain itu, enzim transglutaminase yang memiliki kemampuan untuk meningkatkan jumlah ikatan silang antar protein juga telah digunakan pada proses pembuatan roti komposit sorgum-singkong dan dapat memperbaiki kualitas roti yang dibuat (Onyango et al. 2010b.)

Kelompok kami telah melakukan hidrolisis terhadap tepung sorgum dengan menggunakan enzim $\alpha$-amilase dari Bacillus Sp. $\left(\right.$ Termamyl $^{\circledR}$ ) dan hasil penelitian kami menunjukkan adanya kemampuan enzim tersebut dalam mendegradasi tepung sorgum (Fadhlillah et al. 2015). Oleh karena itu, pada penelitian ini kami melanjutkan penelitian sebelumnya untuk menentukan bagaimana sifat fisikokimia tepung sorgum yang telah didegradasi 
sebagian dengan Termamyl ${ }^{\circledR}$ sebagaimana juga telah dibuktikan terjadinya degradasi granul sorgum yang dibuktikan dengan SEM (Fadhlillah, et al. 2015)

\section{BAHAN DAN METODE}

\section{Bahan}

Tepung sorgum berukuran 100 mesh berasal dari biji sorgum ZH30 yang dikembangkan oleh Fakultas Pertanian Universitas Padjadjaran. $\alpha$-Amilase termofilik (Termamyl ${ }^{\circledR}$ ) dari Bacillus sp. (Bamyfil) dengan aktivitas 4,0 U/g tepung yang diproduksi oleh Novozyme, diperoleh dari Laboratorium Penelitian Jurusan Kimia Fakultas Matematika dan Ilmu Pengetahuan Alam Universitas Padjadjaran.

\section{Volume pengembangan (Chen, 2003)}

Sebanyak 0,50 g tepung sorgum ditimbang dan disuspensikan dalam $45 \mathrm{~mL}$ air suling pada tabung sentrifugasi $50 \mathrm{~mL}$. Sampel disetimbangkan selama 5 menit pada suhu ruang, kemudian dipanaskan selama 30 menit pada suhu $55-95^{\circ} \mathrm{C}$ sambil diaduk terusmenerus. Setelah itu sampel didinginkan sampai suhu ruang dan disentrifugasi pada $1000 \mathrm{rpm}$ selama 15 menit. Tinggi gelnya diukur dan dikonversikan ke dalam volume per unit berat kering sampel.

\section{Pengukuran viskositas}

Pengukuran viskositas digunakan untuk menentukan sifat pembentukan pasta. Tepung sebanyak 30 gram disuspensikan dalam air suling sebanyak $375 \mathrm{~mL}$ kemudian dipanaskan. Pengukuran viskositas dilakukan menggunakan viskometer Brookfield pada suhu 50, 60, 70, 80 dan $90^{\circ} \mathrm{C}$.

\section{Kristalinitas (Hug Iten et al., 2003)}

Kristalinitas ditentukan menggunakan difraktometer sinar-X Xpert PRO dari PANalytical dengan kondisi operasi: voltase target, $40 \mathrm{KV}$; arus,
$100 \mathrm{~mA}$; masa simpan, $5 \mathrm{~min}$; rentang sudut, 5-35'; kecepatan scan, 2,0/mnt; tahap waktu, 4,5 s; lebar celah divergen, 1,00; lebar celah scatter, 1,00 dan lebar celah penerima, 0,60 .

\section{HASIL DAN PEMBAHASAN \\ Pengaruh penambahan Bamyfil terhadap volume} pengembangan tepung sorgum

Kekuatan pengembangan tepung sorgum mengindikasikan kapasitas penahanan air (water holding capacity) dan secara umum digunakan untuk menunjukkan perbedaan jenis-jenis pati dan menguji pengaruh modifikasi pati (Chen, 2003). Gambar 1A menunjukkan volume pengembangan tepung sorgum lebih besar dibandingkan dengan volume pengembangan tepung gandum ketika suhu pemanasan mencapai lebih dari $75^{\circ} \mathrm{C}$. Ada keunikan tersendiri dalam pengembangan tepung sorgum dimana setelah proses pemanasan pada suhu $95^{\circ} \mathrm{C}$ dan sentrifugasi, terdapat dua lapisan (Gambar 1B). Lapisan atas kemudian diuji dengan larutan iodin dan menghasilkan warna biru sehingga diperkirakan lapisan tersebut merupakan amilosa yang keluar dari granul. Goesaert et al. (2009) menyebutkan bahwa ketika proses pemanasan yang menyebabkan gelatinasi, granul pati mengalami pengembangan kemudian pecah dan sebagian atau keseluruhan amilosa keluar dari granul. Amilosa yang keluar dari granul terlihat pada tepung sorgum yang memiliki kandungan amilosa yang tinggi. Penambahan Bamyfil menyebabkan pemotongan rantai amilosa sehingga menurunkan kandungan amilosa. Pecahnya kandungan amilosa pada tepung sorgum terhidrolisis mengurangi kemampuan membentuk gel sehingga volume pengembangan tepung sorgum terhidrolisis tidak sebesar volume pengembangan tanpa hidrolisis.

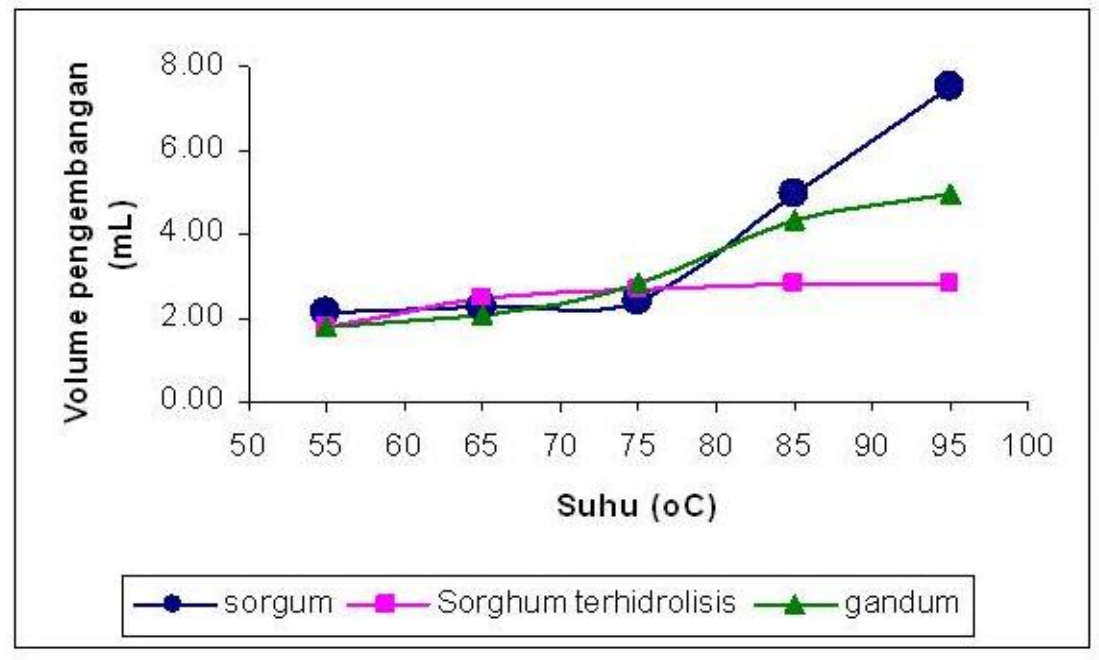

(A)

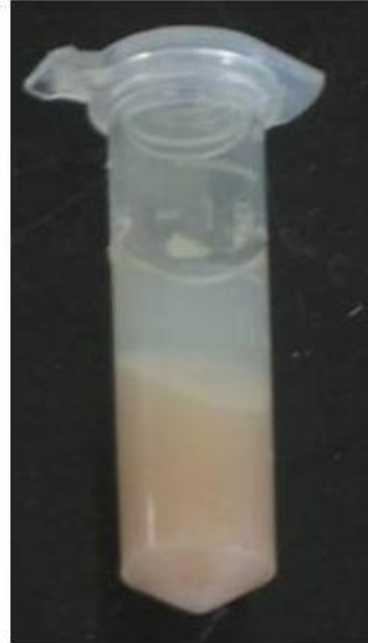

(B)

Gambar 1. Volume pengembangan tepung sorgum sebelum dan setelah penambahan Bamyfil. (A) Grafik pengembangan gel. (B) Tampakan gel sorgum 


\begin{tabular}{|c|c|c|c|}
\hline $\begin{array}{l}\text { Suhu } \\
\left.{ }^{\circ} \mathrm{C}\right)\end{array}$ & Sorgum & $\begin{array}{c}\text { Sorgum } \\
\text { terhidrolisis }\end{array}$ & Gandum \\
\hline 55 & & & \\
\hline 65 & & & \\
\hline 75 & & & \\
\hline 85 & & & \\
\hline 95 & & & \\
\hline
\end{tabular}

Gambar 2. Pengembangan granul tepung sorgum sebelum dan setelah penambahan Bamyfil.

Pengaruh penambahan Bamyfil terhadap sifat pembentukan pasta tepung sorgum

Sifat-sifat pembentukan pasta merupakan peristiwa yang melibatkan pengembangan granul, pelepasan komponen granul dan akhirnya pemecahan granul (Chanapamokkhot \& Thongngam, 2007). Serangkaian perubahan yang akhirnya mengarah pada kehancuran irreversibel susunan molekul granul pati diistilahkan gelatinasi (Goesaert et al., 2005).
Gambar 2 menunjukkan perubahan yang terjadi pada granul ketika proses pembentukan pasta (suhu gelatinasi). Gelatinasi pada sorgum dapat terlihat pada suhu $85^{\circ} \mathrm{C}$ sedangkan tepung gandum dan tepung sorgum terhidrolisis mengalami gelatinasi pada suhu $75^{\circ} \mathrm{C}$.

Selain hilangnya keteraturan molekul dan kristalinitas, proses gelatinisasi juga berkaitan dengan pelarutan pati, utamanya pelepasan amilosa, yang 


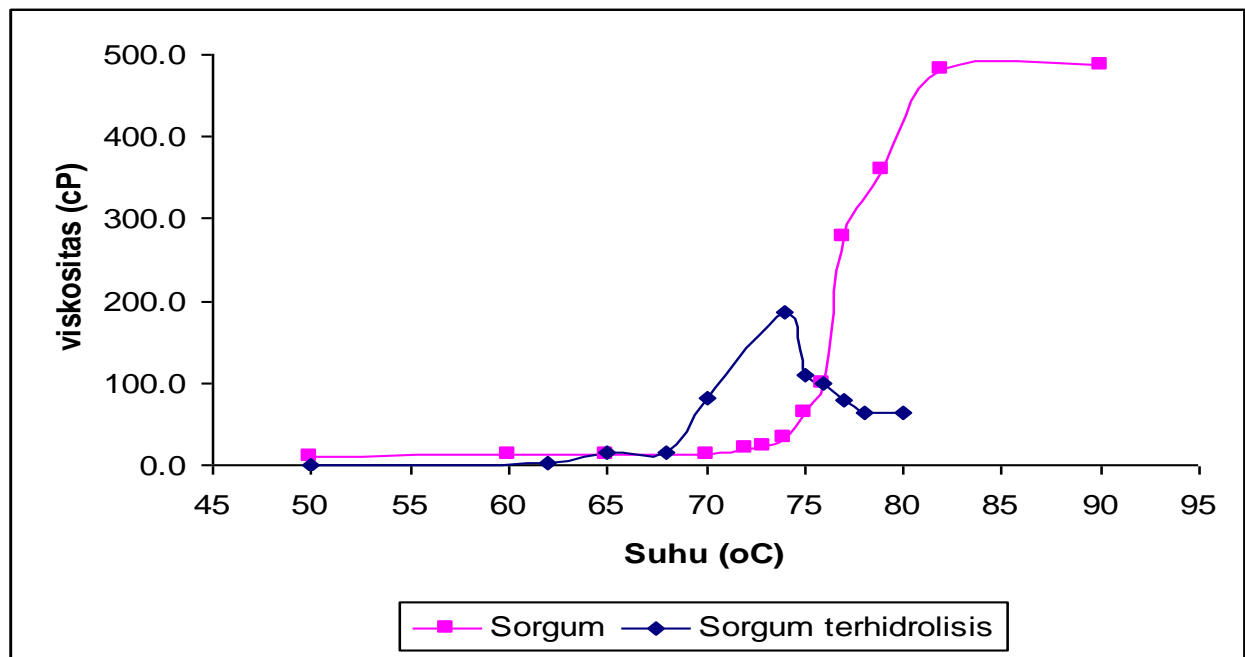

Gambar 3. Pengaruh penambahan Bamyfil terhadap sifat pembentukan pasta (suhu gelatinasi).

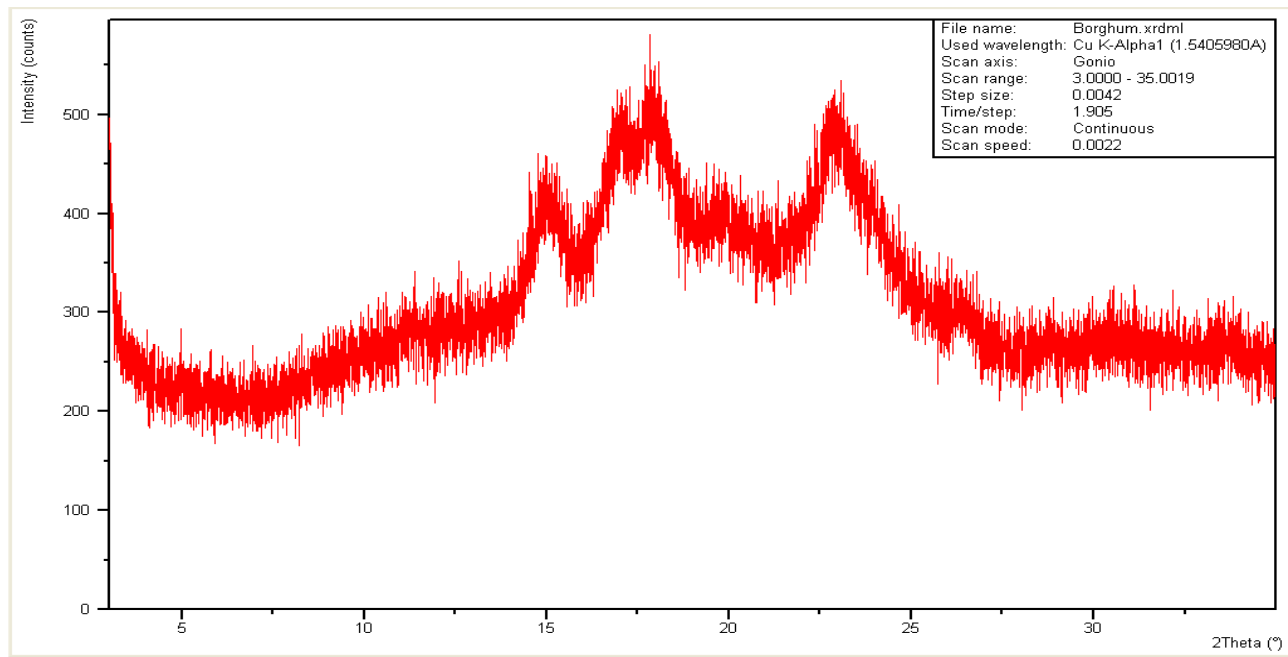

(A)

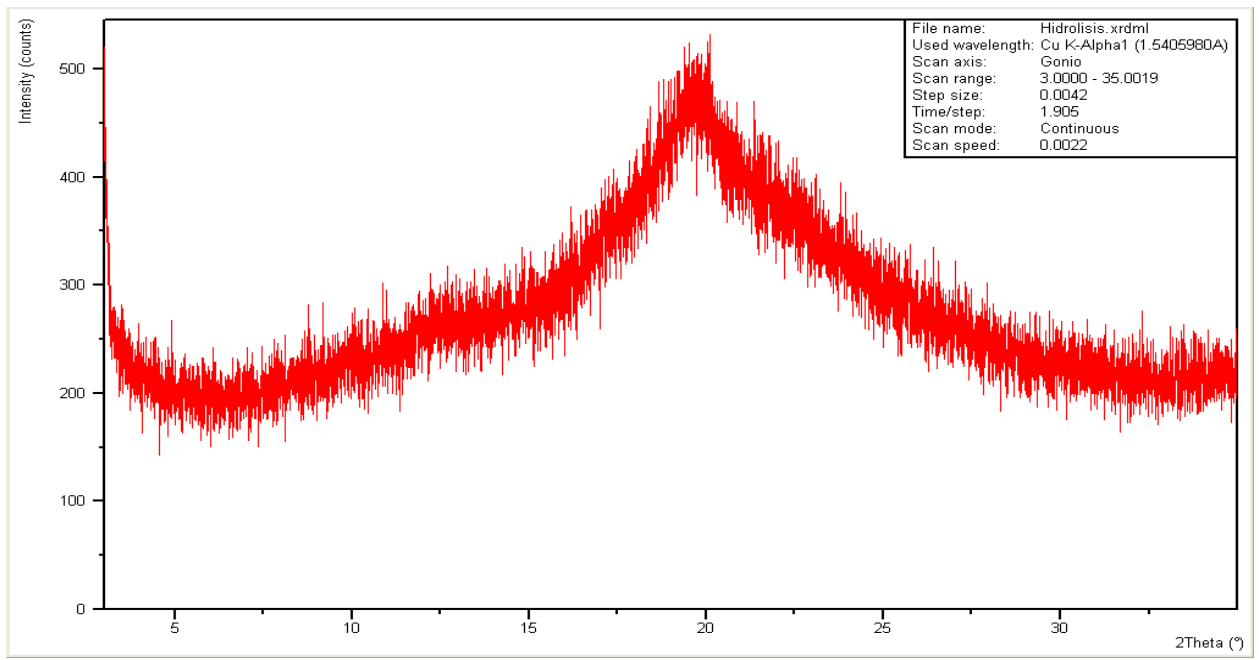

(B)

Gambar 4. Pengaruh Bamyfil terhadap kristalinitas tepung sorgum. (A) Tepung sorgum dan (B) tepung sorgum terhidrolisis. 
meningkatkan viskositas suspensi pati (Goesaert et al., 2005). Karakter viskositas tepung sorgum dan tepung sorgum terhidrolisis dapat dilihat pada Gambar 3. Pada suhu 55 hingga $70^{\circ} \mathrm{C}$ viskositas tepung sorgum cenderung konstan kemudian terjadi peningkatan viskositas setelah melewati suhu $70^{\circ} \mathrm{C}$ hingga suhu gelatinasi dicapai pada suhu $80-85^{\circ} \mathrm{C}$. Penambahan Bamyfil yang mengakibatkan proses hidrolisis amilosa menurunkan viskositas puncak dan suhu gelatinasi yang dicapai pada suhu $73-75^{\circ} \mathrm{C}$. Selama proses hidrolisis, terjadi degradasi pati menjadi maltosa dan dekstrin sehingga gelatinasi lebih mudah terjadi.

\section{Pengaruh penambahan Bamyfil terhadap kristalinitas tepung sorgum}

Difraksi sinar X dapat menunjukkan karakteristik kualitatif struktur kristal pati pada tepung. Menurut Bao (2004), struktur rantai amilopektin yang meliputi panjang rantai, keberadaan cabang, bobot molekul, maupun polidispersitas mempengaruhi kristalinitas, walaupun perlu diingat juga kemungkinan adanya amilosa pada daerah kristal. Selain itu, tingginya suhu gelatinasi dapat menjadi indikasi tingginya kestabilan kristalit pati karena salah satu faktor yang mempengaruhi suhu gelatinasi yaitu panjang rantai amilopektin yang berlainan, kemudian rantai yang lebih panjang akan meningkatkan suhu gelatinisasi (Taylor et al., 2006).

Area antara 13 hingga $25^{\circ}$ pada pola difraksi sinar X pada Gambar 4 menunjukkan bagaimana susunan kristalinitas pati dalam tepung sorgum. Pola difraksi sinar-X dari tepung sorgum menyerupai pola difraksi "white sorgum" yang dilaporkan oleh Boudries et al. (2009) yang umum ditemukan pada pati sereal dan mempunyai beberapa refleksi di $15^{\circ}$, $17^{\circ}, 18^{\circ}$ dan $23^{\circ}$ (Gambar 4A). Setelah penambahan Bamyfil maka muncul refleksi di $20^{\circ}$ (Gambar 4B), tetapi refleksi-refleksi sebelumnya hilang. Hal tersebut menunjukkan granul kehilangan daerahdaerah kristalinnya sehingga menjadi lebih amorf. Perubahan ini terkait dengan perubahan struktur amilopektin maupun penurunan kandungan amilosa dan amilopektin akibat hidrolisis.

\section{KESIMPULAN}

Penambahan Bamyfil 4,0 U/g tepung memberikan pengaruh terhadap sifat fisikokimia tepung sorgum yang meliputi penurunan volume pengembangan sebesar $60 \%$ pada suhu $95^{\circ} \mathrm{C}$, penurunan suhu pembentukan pasta dari $80-85^{\circ} \mathrm{C}$ menjadi $70-75^{\circ} \mathrm{C}$, dan pengurangan refleksi kristalit yang menunjukan perubahan kristalinitas dari semikristalin menjadi amorf.

\section{Ucapan Terima Kasih (Acknowledgment)}

Kami ucapkan terimakasih kepada Kementerian Pendidikan Nasional atas pendanaan penelitian melalui Hibah Pasca pada tahun anggaran 2009.

\section{DAFTAR PUSTAKA}

Bao, J. (2004). The functionality of rice starch. In Ann-Charlotte Eliasson (Ed.), Starch in food. Structure, function and application (pp. 258289). Woodhead Publishing.

Boudries, N., Belhaneche, N., Nadjemi, B., Deroanne, C., Mathluthi, M., Roger, B. \& Sindic, M. (2009). Physicochemical and functional properties of starches from sorghum cultivated in the sahara of Algeria, Carbogydrate Polymers, 78: 475-480.

Chanapamokkhot, H. \& Thongngam, M. (2007). The chemical and physico-chemical properties of sorghum starch and flour, Kasetsart Journal, 41: 343 .

Chen, Z. (2003). Physicochemical properties of sweet potato starches and their application in noodle products. Ph.D. Thesis. University of Wageningen. The Netherlands.

Fadhlillah, M., Soemitro, S. \& Subroto, T. (2015). Potensi Enzim $\alpha$-Amilase dari Bacillus Sp. (Termamyl ${ }^{\circledR}$ ) Untuk Pemrosesan Tepung Sorgum, Chimica et Natura Acta, 3(3): 110115.

Fasano, A. \& Catassi, C. (2001). Current Approaches to Diagnosis and Treatment of Celiac Disease: An Evolving Spectrum, Gastroenterology, 120: 636-651.

Goesaert, H., Brijs, K., Veraverbeke, W.S., Courtin, C.M., Gebruers, K. \& Delcour, J.A. (2005). Wheat flour constituents: how they impact bread quality, and how to impact their functionality, Trends in Food Science and Technology, 16: 12-30.

Goesaert, H., Slade, L., Levine, H., \& Delcour, J.A. (2009). Amylases and bread firming-an integrated view, Journal of Cereal Science, 50: 345-352.

Hug-Iten, S., Escher, F., \& Conde-Petit, B., (2003). Staling of bread: role of amylose and amylopectin and influence of starch-degrading enzymes, Cereal Chemistry, 80: 654-661.

Lagrain, B., Wilderjans, E., Glorieux, C. \& Delcour, J.A. (2013). Role of gluten and starch in crumb structure and texture of fresh and stored straight-dough bread. In Inside Food Symposium (Vol. 4, pp. 9-28).

Onyango, C., Mutungi, C., Unbehend. G. \& Lindhauer, M.G. (2010a). Batter rheology and bread texture of sorghum-based gluten-free formulations modified with native or pregelatinised cassava starch and $\alpha$-amylase, International Journal of Food Science and Technology, 45: 1228-1235.

Onyango, C., Mutungi, C., Unbehend. G. \& Lindhauer, M.G. (2010b). Rheological and baking characteristics of batter and bread prepared from pregelatinised cassava starch and sorghum and modified using microbial 
transglutaminase, Journal of Food Engineering, 97: 465-470.

Phattanakulkaewmorie, N., Paseephol, T. \& Moongngarm, A. (2011). Chemical Compositions and Physico-Chemical Properties of Malted Sorghum Flour and Characteristics of Gluten Free Bread, World Academy of Science, Engineering and Technology, 5(7): 532-538.

Schober, T.J., Messerschmidt, M., Bean, S.R., Park, S.-H. \& Arendt, E.K. (2005). Gluten-Free Bread from Sorghum: Quality Differences Among Hybrids, Cereal Chemistry, 82(4): 394-404.

Taylor, J.R.N., Schober, T.J., \& Beanb, S.R. (2006). Novel food and non-food uses for sorghum and millets, Journal of Cereal Science, 44: 252-271.

Zhu, F. (2014). Structure, Physicochemical Properties, Modifications, and Uses of Sorghum Starch, Comprehensive Reviews in Food Science and Food Safety, 13: 597-610. 